Received: 24-07-2019

(Date-Month-Year)
Revised: 07-04-2020

(Date-Month-Year)
Published: 20-04-2020

(Date-Month-Year)

\title{
ANALISIS KESALAHAN PESERTA DIDIK DALAM MENYELESAIKAN SOAL CERITA ARITMATIKA SOSIAL BERDASARKAN TAHAPAN NEWMAN
}

\author{
Marselina Para Jami' $^{1}$, Tatik Retno Murniasih'2, Timbul Yuwono ${ }^{3}$ \\ ${ }^{1,2,3}$ Pendidikan Matematika, Universitas Kanjuruhan Malang, Indonesia \\ 1jamimarselina98@gmail.com \\ 2tretnom@unikama.ac.id \\ 33timbulyuwono@unikama.ac.id
}

\begin{abstract}
Abstrak. Aritmatika sosial adalah materi yang berkaitan dengan jual beli, untung dan rugi. Berdasarkan obeservasi dan pengalaman didapatkan banyaknya peserta didik yang melakukan kesalahan saat menyelesaikan soal cerita terutama materi Aritmatika Sosial. Dengan demikian, dibutuhkan sebuah metode ilmiah untuk mengatasi dengan cara menganalisis kesalahan tersebut, salah satu metode ilmiah yang bisa digunakan adalah tahapan Newman. Berdasarkan tahapan Newman ada 5 jenis kesalahan peserta didik, yaitu: kesalahan membaca (reading errors), kesalahan memahami (comprehension errors), kesalahan transformasi (transformation errors), kesalahan keterampilan proses (process skill errors), dan kesalahan penulisan jawaban akhir (encoding errors). Pendekatan penelitian yaitu pendekatan kualitatif dengan jenis penelitian deskriptif. Penelitian ini menggunakan isntrumen diantaranya tes tertulis dan wawancara. Subjek wawancara sebanyak 5 peserta didik yang diambil berdasarkan tipe kesalahan berdasarkan tahapan Newman. Dari hasil penelitian menunjukan yaitu persentase kesalahan membaca (reading errors) sebesar 0\%, kesalahan memahami sebesar (comprehension errors) sebesar 54\%, kesalahan transformasi (transformation errors) sebesar 92\%, kesalahan keterampilan proses (process skill errors) sebesar 54\%, dan kesalahan penulisan jawaban akhir (encoding errors) sebesar $61 \%$.
\end{abstract}

Kata Kunci: analisis kesalahan; soal cerita; aritmatika sosial; tahapan newman.

\begin{abstract}
Abstrack. Social Arithmetic is material relating to buying and selling, profit and loss. Based on the observation and experience, it was found that there were many students who made mistakes when solving story problems, especially Social Arithmetic. Thus, a scientific method is needed to overcome by analyzing these errors, one of the scientific methods that can be used is the Newman method. Based on Newman's method there are 5 types of student errors, namely: reading errors, comprehension errors, transformation errors, process skill errors, and final answer writing errors. The research approach is a qualitative approach with descriptive research types. This study uses instruments including written tests and interviews. The interview subjects were 5 students taken based on the type of error based on Newman's method. The results showed that the percentage of reading errors was $0 \%$, comprehension errors 54\%, transformation errors $92 \%$, process skill errors 54\%, and encoding errors $61 \%$.
\end{abstract}

Keywords: error analysis; strory matter; social arithmetic; newman method.

\section{Pendahuluan}

Matematika merupakan salah mata pelajaran yang memiliki peranan penting dalam kehidupan sehari-hari, misalnya menimbang jagung dan padi, mengukur luas tanah, melakukan jual, beli, menghitung untung atau rugi pada suatu penjualan dan sebagainya. Abdurrahman
(2012) mengatakan semua orang harus mempelajari matematika karena merupakan sarana untuk memecahkan masalah kehidupan sehari-hari. Menurut Sutjipto (2005) matematika merupakan salah satu matapelajaran yang penting yang harus dikuasai peserta didik di 
sekolah karena banyak kegunaannya di kehidupan sehari-hari.

Tujuan utama pembelajaran matematika adalah untuk membantu peserta didik mengembangkan kemampuannya dalam mengerjakan dan menyelesaikan permasalahan matematika dalam kehidupan sehari - hari. Keberhasilan matematika dilihat dari tidak adanya kesulitan atau kesalahan belajar matematika. Menurut Abdurrahman (2012) mengatakan bahwa kesulitan belajar yang dihadapi peserta didik ditandai dalam beberapa kesalahan umum dalam mengerjakan soal matematika, seperti kesalahan memahami simbol, nilai tempat, perhitungan, penggunaan proses yang salah dan tulisan yang tidak dapat dibaca. Matematika dianggap sebagai sesuatu yang sulit dan rumit terlalu banyak simbol, banyak hitungan, banyak rumus yang susah dihafalkan membuat peserta didik malas untuk mempelajarinya. Menurut Budiyono (2008) soal cerita masih merupakan soal yang cukup sulit bagi sebagian peserta didik. Salah satu soal cerita yang sering terjadi kesalahan dalam penyelesaiannya adalah materi aritmatika sosial.

Berdasarkan informasi dari guru matematika dan pengalaman peneliti selama magang 3 di salah satu SMP swasta di Pakisaji, diperoleh soal cerita pada materi aljabar merupakan soal yang dianggap sulit. Untuk mempermudah peserta didik dalam menyelesaikan bentuk soal cerita aritmatika sosial dibutuhkan suatu alat untuk menganalisis kesalahan. Pada penelitian ini, alat analisis yang digunakan adalah analisis kesalahan Newman. White (2005) berpendapat bahwa metode Newman adalah suatu pemilihan metode yang memiliki kredibilitas tinggi. Analisis kesalahan Newman dipilih untuk memahami jenisjenis kesalahan peserta didik saat menyelesaikan soal cerita. Newman menemukan jenis - jenis kesalahan yang terjadi pada pekerjaan peserta didik saat peserta didik menyelesaikan masalah berbentuk uraian, yaitu: (1) kesalahan membaca (reading errors), (2) kesalahan memahami masalah (comprehension errors), (3) tranformasi (transformation), (4) kesalahan keterampilan proses (process skill errors), dan (5) kesalahan penulisan jawaban (encoding errors).

Penelitian sebelumnya yang berkaitan dengan tahapan analisis kesalahan Newman pada materi Aritmatika Sosial dilakukan oleh(Susilowati \& Ratu, 2018; Sudiono, 2017;Amini \&Yunianta, 2018). Hasil penelitian Susilowati \& Ratu (2018) menunjukkan pengambilan tiga subjek penelitian berdasarkan kesalahan terbanyak yang dilakukan dan selanjutnya diberi scaffolding. Hasil penelitian Sudiono (2017) menggunakan subjek berdasarkan kemampuan siswa secara heterogen. Sedangkan hasil penelitian Amini \& Yunianta (2018) menggunakan kemampuan siswa dan scaffolding. Perbedaan penelitian sebelumnya dengan yang akan peneliti lakukan yaitu cara pengambilan subjek. Subjek pada penelitian sebelumnya dipilih berdasarkan kemampuan yaitu rendah, sedang dan tinggi. Sedangkan subjek pada penelitian ini dipilih berdasar tipe kesalahan sesuai tahapan Newman. Tujuan penelitian untuk mendeskripsikan kesalahan siswa berdasarkan tahapan Newman. Penelitian ini penting dilakukan agar kesalahan serupa dapat diminimalisir. Berdasarkan hasil observasi dan penelitian sebelumnya, maka analisis kesalahan pada materi Aritmatika Sosial merupakan hal yang perlu dilakukan.

\section{Metode Penelitian}

Dalam penelitian ini peneliti menggunakan pendekatan penelitian kualitatif untuk lebih cermat melihat kesalahan peserta didik dengan metode Newman. Moleong (2017) mengatakan 
bahwa penelitian kualitatif adalah suatu penelitian yang bertujuan untuk memahami persepsi, perilaku, motivasi, dan tindakan secara holistik dengan cara deskriptif dalam bentuk kata-kata. Peneliti dalam penelitian menggunkan jenis penelitian deskriptif. Menurut Arikunto (2013) bahwa penelitian deskriptif adalah penelitian yang menyelidiki keadaan, kondisi atau hal lain-lain, yang sudah disebutkan, yang hasilnya dipaparkan dalam bentuk laporan penelitian. Kehadiran peneliti sangatlah penting dan sangat diperlukan dalam penelitian ini karena peneliti berperan sebagai pengumpul data dan berperan sebagai pengamat selama kegiatan penelitian dari perencanaan sampai penulisan laporan penelitian. Penelitian ini dilakukan di salah satu SMP swasta di Pakisaji. Kelas yang dijadikan subjek penelitian adalah kelas VII A. Berdasarkan hasil tes maka akan dipilih subjek penelitian berdasarkan tipe kesalahannya. Selanjutnya akan dilakukan wawancara guna mendapatkan informasi lebih dalam tentang kesalahan peserta didik dalam menyelesaikan soal cerita aritmatika sosial berdasarkan tahapan Newman. Pengambilan subjek penelitian dapat dilihat pada Gambar 1.

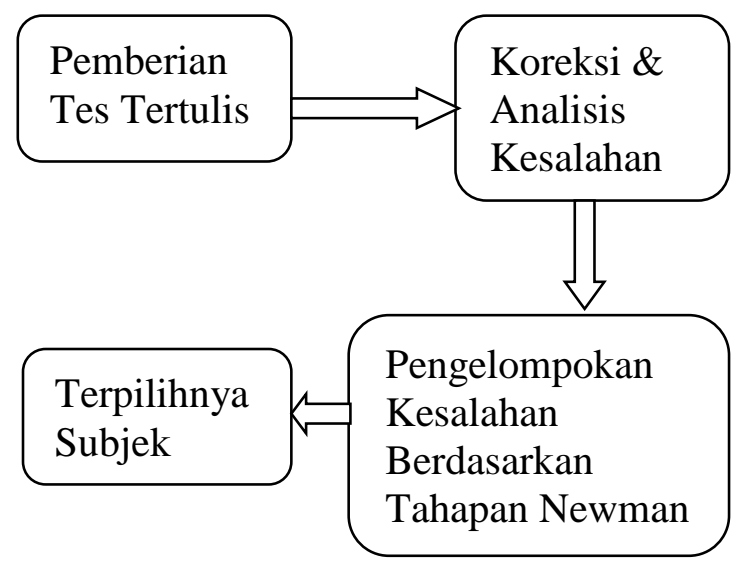

Gambar 1. Pengambilan Subjek

Sesuai Gambar 1. Pemberian tes tertulis pada peserta didik merupakan kegiatan pertama yang dilakukan, berikutnya hasil tes tertulis peserta didik akan dikoreksi dan dianalisis kesalahannya. Setelah dikoreksi dan dianalisis, data akan dikelompokkan berdasarkan tipe kesalahan Newman, berikutnya akan dipilih perwakilan dari setiap tipe kesalahan Newman untuk diwawancara.

Berikut metode pengumpulan data yang digunakan peneliti.

a. Tes Tertulis

Tanggapan hasil tes dapat mengukur kemampuan peserta didik. Tes yang diberikan pada peserta didik divalidasi terlebih dahulu sebelum digunakan.

b. Wawancara

Pada penelitian digunakan tahapan wawancara tak tersutruktur. Wawancara tak terstruktur menurut Sugiyono (2015) adalah wawancara yang telah tersusun secara sistematis dan lengkap untuk pengumpulan datanya. Pedoman wawancara yang digunakan berupa pertanyaan garis besarnya saja. Wawancara dalam penelitian ini bertujuan untuk memperkuat data tentang bentuk kesalahan peserta didik berdasarkan tahapan Newman, yaitu: 1) tahap membaca (reading); 2) tahap memahami (comprehension); 3) tahap transformasi (transformation); 4) tahap keterampilan (process skill); dan 5) tahap penulisan (endcoding).

Jenis analisis data yang digunakan dalam penelitian ini menurut Miles dan Huberman sebagaimana dikutip oleh Sugiyono (2015), tahapan analisis data dalam penilitian ini, yaitu:

a. Reduksi Data

Peneliti memfokuskan pada hal-hal yang penting. Selanjutnya dicari tema agar memudahkan pada pengumpulan data selanjutnya.

b. Penyajian Data

Peneliti menyajikan dalam bentuk teks uraian singkat yang bersifat naratif, gambar dan grafik. Hal ini sesuai dengan pendapat Miles dan Huberman yang 
mengatakan penyajian data dapat dalam bentuk teks naratif, chart, matriks atau gambar (Sugiyono, 2015).
c. Verifikasi
Data
(Penarikan
Kesimpulan)

Setelah proses pengelompokan data menurut Miles dan Huberman (dalam Sugiyono, 2015) adalah penarikan kesimpulan dan verifikasi. Pada penelitian ini, penarikan kesimpulan dari bentukbentuk kesalahan peserta didik dalam menyelesaikan soal cerita aritmatika sosial menurut tahapan analisis kesalahan Newman.

\section{Hasil dan Pembahasan}

Tes tulis pada penelitian ini dilaksanakan pada tanggal 17 Januari 2019 yang diikuti oleh 20 peserta didik terdiri dari 14 laki-laki dan 6 perempuan. Peneliti memberikan soal tes cerita Aritmatika Sosial sebanyak 3 butir soal. Peserta didik diberikan waktu 40 menit untuk mengerjakan soal tes, dimulai dari pukul 10.00 WIB sampai dengan pukul 10.40 WIB. Setelah melakukan rekapitulasi data hasil tes tertulis, selanjutnya menentukan peserta didik untuk dijadikan subjek penelitian. Subjek penelitian dipilih sebanyak 5 peserta didik, dimana dari subjek tersebut di kelompokkan berdasarkan tipe kesalahannya. Secara umum pemilihan subjek wawancara dapat dilihat pada Tabel 1 sebagai berikut:

Tabel 1.Pemilihan Subjek Wawancara

\begin{tabular}{|c|c|c|}
\hline Soal & Calon Subjek & Subjek \\
\hline 1 & 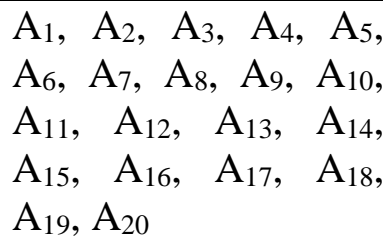 & $\begin{array}{lr}\mathrm{A}_{1}, & \mathrm{~A}_{8}, \\
\mathrm{~A}_{10}, & \mathrm{~A}_{12}, \\
\mathrm{~A}_{13} & \end{array}$ \\
\hline 2 & 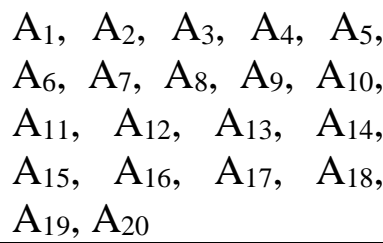 & $\begin{array}{l}A_{8}, \quad A_{10}, \\
A_{12}, A_{13}\end{array}$ \\
\hline
\end{tabular}

$3 \quad \mathrm{~A}_{1}, \mathrm{~A}_{2}, \mathrm{~A}_{3}, \mathrm{~A}_{4}, \mathrm{~A}_{5}, \mathrm{~A}_{8}, \mathrm{~A}_{10}$, $\mathrm{A}_{6}, \mathrm{~A}_{7}, \mathrm{~A}_{8}, \mathrm{~A}_{9}, \mathrm{~A}_{10}, \mathrm{~A}_{12}, \mathrm{~A}_{13}$

$\mathrm{A}_{11}, \mathrm{~A}_{12}, \mathrm{~A}_{13}, \mathrm{~A}_{14}$,

$\mathrm{A}_{15}, \mathrm{~A}_{16}, \mathrm{~A}_{17}, \mathrm{~A}_{18}$,

$\mathrm{A}_{19}, \mathrm{~A}_{20}$

Berikut ini merupakan perwakilan hasil tes tertulis dan hasil wawancara dari subjek penelitian:

1. Peserta Didik $A_{12}$ yang mewakili soal nomor 1

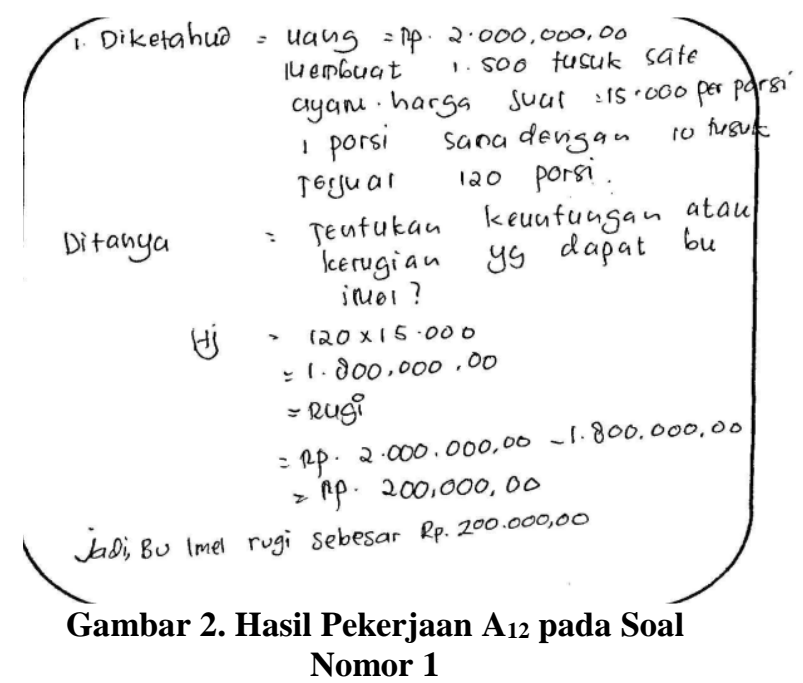

Subjek $\mathrm{A}_{12}$ melakukan kesalahan pada tahap transformasi (transformation errors) dan penulisan jawaban akhir (encoding errors) yaitu tidak menuliskan rumus yang digunakan untuk menyelesaikan soal no. 1. Berikut cuplikan wawancara dengan subjek $\mathrm{A}_{12}$ :

$\begin{array}{ll}\text { Peneliti } & : \text { :Coba bacakan } \\ & \text { kembali soal no. 1?" } \\ & : \text { " Bu Imel seorang pedagang } \\ & \text { sate ayam di daerah Sukun, } \\ & \text { setiap pagi Bu Imel pergi ke } \\ & \text { pasar untuk membeli bahan } \\ & \text { pokok untuk membuat sate } \\ & \text { ayam. Untuk membeli bahan } \\ & \text { pokok tersebut, Bu Imel } \\ & \text { mengeluarkan uang sebesar Rp } \\ & \text { 2.000.000,00. Bu Imel mampu } \\ & \text { membuat 1.500 tusuk sate } \\ & \text { ayam dengan bahan baku } \\ & \text { tersebut dan dijual seharga Rp } \\ & 15.000,00 \text { per porsi, 1 porsi }\end{array}$


sama dengan 10 tusuk. Pada waktu itu $\mathrm{Bu}$ Imel mampu menjual 120 porsi sate ayam. Tentukan keuntungan atau kerugian yang didapat $\mathrm{Bu}$ Imel!"

Peneliti :"Apakah dari soal tersebut ada yang kamu anggap sulit?"

$\mathrm{A}_{12}$ :"Tidak ada Bu..."

Peneliti :"Apakah kamu sudah menulis secara lengkap apa yang diketahui?"

$\mathrm{A}_{12} \quad$ :"Sudah Bu"

Peneliti :"Apakah kamu sudah menulis apa yang ditanyakan?"

$\mathrm{A}_{12} \quad$ :"Sudah Bu"

Peneliti :'Lalu cara apa yang kamu gunakan untuk menyelesaikan soal tersebut?"

$\mathrm{A}_{12} \quad$ :'Pertama menentunkan harga jualnya, lalu harga jualnya dimasukan kedalam rumus menentukan kerugian dan ketemulah hasilnya Bu.."

Peneliti :"Apakah langkah-langkah yang kamu kerjakan sudah sesuai dengan yang kamu katakan?"

$\mathrm{A}_{12} \quad$ :'Sudah $\mathrm{Bu}$, eh..lupa rumusnya Bu hehe"

Peneliti :"Apakah kamu sudah menuliskan jawaban akhir dengan lengkap?"

$\mathrm{A}_{12} \quad$ :'Sudah Bu..”

2. Peserta Didik $A_{10}$ yang mewakili soal nomor 2

$$
\begin{aligned}
& \text { 2. Membeti }=2 \text { lusin pengaris dengan harga \&p. } 35 \cdot 000,00
\end{aligned}
$$

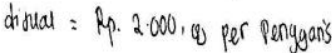

$$
\begin{aligned}
& H_{j}=20 \times 2000,00 \\
& \text { keuniungan }=\mathrm{HJ}-\mathrm{HB} \\
& =40 \cdot 000 \cdot 00-35 \cdot 000 \cdot 00 \\
& =13.000 .00 \\
& \text { Persentase } u=\frac{13.0000}{33000.00} \times 100 \% \\
& =37 \%
\end{aligned}
$$

Gambar 3. Hasil Pekerjaan A10pada Soal Nomor 2
Subjek $\mathrm{A}_{10}$ melakukan kesalahan pada tahap memahami (comprehension errors), tahap transformasi (transformation errors) dan tahap penulisan jawaban akhir (encoding errors). Subjek $\mathrm{A}_{10}$ tidak menuliskan kata diketahui, tidak menuliskan apa yang ditanyakan, tidak menuliskan dengan lengkap harga jual, tidak menuliskan rumus untuk menghitung persentase rugi dan tidak menuliskan dengan lengkap jawaban akhir dari soal no. 2. Berikut cuplikan wawancara dengan subjek $A_{13}$ :

Peneliti :"Coba bacakan kembali soal no. 2?"

$\mathrm{A}_{10} \quad$ :'Dean membeli 2 lusin penggaris dengan harga $\mathrm{Rp}$ 35.000,00. Jika penggaris tersebut dijual lagi oleh Dean seharga Rp 2.000,00 per penggaris, maka berapa persentase keuntungan yang peroleh Dean dari hasil penjualan penggaris?"

Peneliti :"Apakah dari soal tersebut ada yang kamu anggap sulit?"

$\mathrm{A}_{10} \quad$ :'Tidak ada Bu..."

Peneliti :"Apakah kamu sudah menulis secara lengkap apa yang diketahui?"

A $10 \quad$ :" Lupa 'diketahuinya' Bu..hehe"

Peneliti :'Apakah kamu suda menulis apa yang ditanyakan?"

$\mathrm{A}_{10} \quad$ :'Waduh $\mathrm{Bu}$, malas saya $\mathrm{Bu}$ nulis 'yang ditanyakan'..hehe"

Peneliti :'Lalu cara apa yang kamu gunakan untuk menyelesaikan soal tersebut?"

A $10 \quad$ :'Pertama menentunkan harga jualnya, lalu tentukan besar keuntungan yang diperoleh Dean kemudian, dari keuntungan tersebut dimasukan ke rumus persentase keuntungan untuk menjadapatkan jawabannya Bu"

Peneliti :"Apakah langkah-langkah yang kamu kerjakan sudah sesuai dengan yang kamu katakan?"

$\mathrm{A}_{10} \quad$ :'Belum Bu." 
Peneliti :"Apakah kamu sudah menuliskan jawaban akhir dengan lengkap?"

$\mathrm{A}_{10}$ Bu'jadi, persentase keuntungan yang diperoleh Dean sebesar $37 \%$. Lupa saya tulis,, Bu"

\section{Peserta Didik A13 yang mewakili soal} nomor 3

$$
\begin{aligned}
& \text { 3.A.Hj }=4.500 .000-1.500 .000=3.000 .000 \\
& \text { B. Presentase rugi }=\frac{15.0600 .000}{4.500 .000} \times 100 \%=50 \%
\end{aligned}
$$

\section{Gambar 4. Hasil Pekerjaan A13pada Soal Nomor 3}

Subjek $\mathrm{A}_{13}$ melakukan kesalahan pada tahap memahami (comprehension errors), tahap transformasi (transformation errors), tahap keterampilan proses (process skill errors) dan tahap penulisan jawaban akhir (encoding errors). Subjek $\mathrm{A}_{13}$ tidak menuliskan apa yang diketahui, tidak menuliskan apa yang ditanyakan, tidak menuliskan rumus yang digunakan, melakukan kesalahan berhitung, dan tidak menuliskan jawaban akhir dengan lengkap

\begin{tabular}{|c|c|}
\hline Peneliti & $\begin{array}{l}\text { :"Coba bacakan kembali soal no. } \\
\text { 3?"” }\end{array}$ \\
\hline \multirow[t]{4}{*}{$\mathrm{A}_{13}$} & $\begin{array}{l}\text { :'Bu Vara membeli lemari es } \\
\text { dengan kualitas terbaik seharga }\end{array}$ \\
\hline & $\begin{array}{l}\mathrm{Rp} 4.500 .000,00 \text {. Lemari es } \\
\text { tersebut dijual kembali oleh } \mathrm{Bu} \\
\text { Vara dan mengalami kerugian }\end{array}$ \\
\hline & $\begin{array}{lll}\text { sebesar } & \mathrm{Rp} & 1.500 .000,00 . \\
\text { Tentukan: } & & \end{array}$ \\
\hline & $\begin{array}{l}\text { a. Harga jual lemari es tersebut } \\
\text { b. Persentase kerugian" }\end{array}$ \\
\hline Peneliti & $\begin{array}{l}\text { :"Apakah dari soal tersebut ada } \\
\text { yang kamu anggap sulit?" }\end{array}$ \\
\hline $\mathrm{A}_{13}$ & :"Tidak Bu..." \\
\hline Peneliti & $\begin{array}{l}\text { :"Apakah kamu sudah menulis } \\
\text { secara lengkap apa yang } \\
\text { diketahui?" }\end{array}$ \\
\hline $\mathrm{A}_{13}$ & :" Lupa Bu" \\
\hline
\end{tabular}
soal no. 3. Berikut cuplikan wawancara

\begin{tabular}{|c|c|}
\hline Peneliti & $\begin{array}{l}\text { :"Apakah kamu suda menulis } \\
\text { apa yang ditanyakan?" }\end{array}$ \\
\hline $\mathrm{A}_{13}$ & :’Tidak Bu, hehe" \\
\hline Peneliti & $\begin{array}{l}\text { :'Lalu cara apa yang kamu } \\
\text { gunakan untuk menyelesaikan } \\
\text { soal tersebut?" }\end{array}$ \\
\hline $\mathrm{A}_{13}$ & $\begin{array}{l}\text { :'Pertama menentunkan harga } \\
\text { jualnya, lalu menghitung } \\
\text { persentase kerugiannya Bu" }\end{array}$ \\
\hline Peneliti & $\begin{array}{l}\text { :"Apakah langkah-langkah } \\
\text { yang kamu kerjakan sudah } \\
\text { sesuai dengan yang kamu } \\
\text { katakan?" }\end{array}$ \\
\hline $\mathrm{A}_{13}$ & :’Rumusnya lupa Bu.." \\
\hline Peneliti & $\begin{array}{l}\text { :"Apakah jawabanmu sudah } \\
\text { benar?" }\end{array}$ \\
\hline $\mathrm{A}_{13}$ & $\begin{array}{l}\text { :"Belum Bu, saya salah } \\
\text { menghitung } \\
\text { kerugiannya" }\end{array}$ \\
\hline Peneliti & $\begin{array}{lll}\text { :"Apakah kamu sudah } \\
\text { menuliskan jawaban akhir } \\
\text { dengan lengkap?" }\end{array}$ \\
\hline $\mathrm{A}_{13}$ & :’kayaknya belum Bu.." \\
\hline
\end{tabular}
dengan subjek $\mathrm{A}_{13}$ :

Persentase kesalahan peserta didik ditunjukkan dalam Tabel 2.seperti berikut:

\begin{tabular}{|c|c|c|c|c|c|c|}
\hline \multirow[t]{2}{*}{$\begin{array}{c}\text { Subjek } \\
\text { Penelitian }\end{array}$} & \multirow[t]{2}{*}{$\begin{array}{c}\text { Nomor } \\
\text { Soal }\end{array}$} & \multicolumn{5}{|c|}{$\begin{array}{c}\text { Kesalahan Berdasarkan } \\
\text { Tahapan Newman }\end{array}$} \\
\hline & & $\mathbf{T}_{1}$ & $\mathbf{T}_{2}$ & $\mathbf{T}_{3}$ & $\mathbf{T}_{4}$ & $\mathbf{T}_{5}$ \\
\hline $\mathrm{A}_{1}$ & 1 & $\sqrt{ }$ & $\mathrm{X}$ & $\mathrm{X}$ & $\sqrt{ }$ & $\sqrt{ }$ \\
\hline \multirow{3}{*}{$\mathrm{A}_{8}$} & 1 & $\sqrt{ }$ & $\sqrt{ }$ & $\mathrm{X}$ & $\sqrt{ }$ & $\mathrm{X}$ \\
\hline & 2 & $\sqrt{ }$ & $\sqrt{ }$ & $\mathrm{X}$ & $\mathrm{X}$ & $\sqrt{ }$ \\
\hline & 3 & $\sqrt{ }$ & $\sqrt{ }$ & $\mathrm{X}$ & $\mathrm{X}$ & $\sqrt{ }$ \\
\hline \multirow{3}{*}{$\mathrm{A}_{10}$} & 1 & $\sqrt{ }$ & $\mathrm{X}$ & $\mathrm{X}$ & $\sqrt{ }$ & $\mathrm{X}$ \\
\hline & 2 & $\sqrt{ }$ & $\mathrm{X}$ & $\mathrm{X}$ & $\sqrt{ }$ & $\mathrm{X}$ \\
\hline & 3 & $\sqrt{ }$ & $\mathrm{X}$ & $\mathrm{X}$ & $\mathrm{X}$ & $\sqrt{ }$ \\
\hline \multirow{3}{*}{$\mathrm{A}_{12}$} & 1 & $\sqrt{ }$ & $\sqrt{ }$ & $X$ & $\sqrt{ }$ & $\sqrt{ }$ \\
\hline & 2 & $\sqrt{ }$ & $\sqrt{ }$ & $\mathrm{X}$ & $\sqrt{ }$ & $\mathrm{X}$ \\
\hline & 3 & $\sqrt{ }$ & $\sqrt{ }$ & $\mathrm{X}$ & $\mathrm{X}$ & $\mathrm{X}$ \\
\hline \multirow{3}{*}{$\mathrm{A}_{13}$} & 1 & $\sqrt{ }$ & $\mathrm{X}$ & $\sqrt{ }$ & $\mathrm{X}$ & $\mathrm{X}$ \\
\hline & 2 & $\sqrt{ }$ & $\mathrm{X}$ & $\mathrm{X}$ & $X$ & $X$ \\
\hline & 3 & $\sqrt{ }$ & $\mathrm{X}$ & $\mathrm{X}$ & $X$ & $\mathrm{X}$ \\
\hline \multicolumn{2}{|c|}{ Total Kesalahan } & 0 & 7 & 12 & 7 & 8 \\
\hline \multicolumn{2}{|c|}{ Kesalahan (\%) } & $0 \%$ & $54 \%$ & $92 \%$ & $54 \%$ & $61 \%$ \\
\hline
\end{tabular}

Tabel 2.Kesalahan yang Dilakukan Subjek Penelitian

$\mathrm{T}_{1}$ : Kesalahan Membaca (reading errors)

$\mathrm{T}_{2}$ : Kesahalan Memahami (comprehensio $n$ errors) 
$\mathrm{T}_{3}$ : Kesalahan Tranformasi (transformati on errors)

$\mathrm{T}_{4}$ : Kesahalahan Keterampilan Proses (process skill errors)

$\mathrm{T}_{5}$ : Kesalahan Penulisan Jawaban Akhir (encoding errors)

$\mathrm{X}$ : Melakukan Kesalahan

$\sqrt{ }$ : Tidak Melakukan Kesalahan

Berdasarkan data pada Tabel 2 dapat diketahui bahwa kesalahan yang paling banyak dilakukan peserta didik adalah kesalahan transformasi yaitu sebesar 92\%, kesalahan penulisan jawaban akhir yaitu sebesar $61 \%$, kesalahan memahami dan keterampilan proses yaitu sebesar 54\%, sedangkan untuk kesalahan membaca tidak terjadi kesalahan membaca. Lebih jelasnya dapat dilihat pada Gambar 4 berikut:

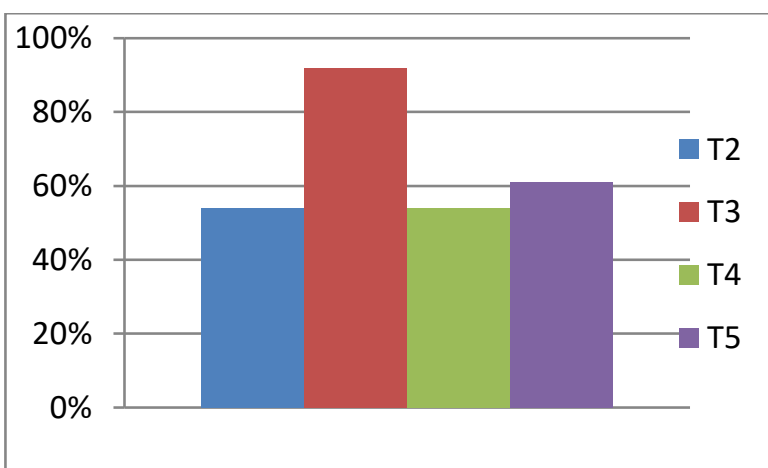

\section{Gambar 5. Grafik Persentase Kesalahan Peserta Didik}

Jha (2012) dan Singh, dkk. (2010) berpendapat bahwa kesalahan membaca soal (reading errors) merupakan suatu kesalahan yang disebabkan karena peserta didik tidak mampu: mengenal/membaca simbol - simbol yang ada pada soal; 2) mengerti makna pada simbol tersebut; atau 3) memaknai kata kunci yang terdapat pada soal tersebut. Pada penelitian ini tidak ada subjek penelitian yang melakukan kesalahan membaca baik di soal nomor 1 , nomor 2 maupun nomor 3. Faktor yang menyebabkan peserta didik melakukan kesalahan membaca adalah tidak mampu memaknai kata kunci dalam soal. Faktor yang menyebabkan terjadinya kesalahan membaca dalam menyelesaikan soal cerita sangat jarang terjadi, hal tersebut sesuai dengan temuan beberapa penelitian. Hal ini sejalan dengan Sudiono (2017; Amalia, 2017)yang menyebutkan bahwa kesalahan membaca jarang terjadi karena bentuk soal menggunakan bahasa Indonesia yang baik dan tidak banyak mengandung simbol.

Jha (2012) dan Singh, dkk. (2010) berpendapat bahwa kesalahan memahami masalah (comprehension errors) merupakan kesalahan yang disebabkan karena tidak mampu: 1) memahami arti keseluruhan dari suatu soal; 2) menuliskan dan menjelaskan apa yang diketahui dari soal; 3) menuliskan dan menjelaskan apa yang ditanya dari soal tersebut. Pada penelitian ini, subjek penelitian yang melakukan kesalahan tersebut adalah subjek penelitian $\mathrm{A}_{1}, \mathrm{~A}_{10}$, dan $\mathrm{A}_{13}$ pada soal nomor 1 , subjek $A_{1}, A_{10}$ dan $A_{13}$ pada soal nomor 2 , subjek $A_{10}$ dan $A_{13}$ pada soal nomor 3. Sedangkan subjek $\mathrm{A}_{8}$ dan $\mathrm{A}_{12}$ tidak melakukan kesalahan memahami. Faktor terjadinya kesalahan memahami karena peserta didik tidak menuliskan apa yang diketahui dan apa yang ditanyakan. Hal ini sejalan dengan (Rahmawati \& Permata, 2018)yang menyatan bahwa kesalahan memahami terjadi ketika peserta didik tidak mampu menentukan dan menuliskan apa yang diketahui dan apa yang ditanyakan.

Menurut Jha (2012) dan Singh, dkk. (2010) kesalahan transformasi (transformation errors) merupakan suatu kesalahan yang disebabkan karena peserta didik tidak mampu: 1) menentukan rumus yang akan digunakan untuk menyelesaikan soal tersebut; 2) menentukan operasi matematika atau rangkaian operasi untuk menyelesaikan soal tersebut; 3) mengidentifikasi operasi, atau serangkaian operasi. Pada penelitian ini, subjek penelitian yang melakukan 
kesalahan tersebut adalah subjek penelitian $\mathrm{A}_{1}, \mathrm{~A}_{8}, \mathrm{~A}_{10}$ dan $\mathrm{A}_{12}$ pada soal nomor 1 , subjek $A_{8}, A_{10}, A_{12}$, dan $A_{13}$ pada soal nomor 2 , subjek $A_{8}, A_{10}, A_{12}$ dan $A_{13}$ pada soal nomor 3. Faktor penyebab terjadinya kesalahan transformasi karena peserta didik tidak menuliskan rumus yang digunakan untuk menyelesaikan soal cerita. Hal ini sejalan dengan penelitian(Oktaviana, 2017)yang menyatakan bahwa kesalahan transformasi terjadi bila peserta didik tidak menuliskan metode yang akan digunakan, menuliskan metode yang tidak tepat, atau tidak lengkap menuliskan metode karena tidak menuliskan rumus matematik yang diperlukan untuk menyelesaikan soal.

Menurut Jha (2012) dan Singh (2010) kesalahan keterampilan (process skill errors)adalah suatu kesalahan yang disebabkan karena peserta didik tidak mampu: 1) mengetahui proses algoritma untuk menyelesaikan soal meskipun sudah mampu menentukan rumus dengan tepat atau 2) menjalankan prosedur dengan benar meskipun sudah mampu menentukan operasi matematika yang digunakan dengan tepat. Peserta didik dapat dan mampu memilih operasi mana yang akan dignakan nama terjadi kesalahan pada proses perhitungan. Pada penelitian ini, subjek penelitian yang melakukan kesalahan tersebut adalah subjek penelitian $\mathrm{A}_{13}$ pada soal nomor 1, subjek $A_{8}$ dan $A_{13}$ pada soal nomor 2, subjekA8, $A_{10}, A_{12}$, dan $A_{13}$ pada soal nomor 3. Fakrot penyebab terjadinya kesalahan keterampilan proses adalah peserta didik kurang teliti dalam menghitng sehingga hasil yang diperoloeh tidak sesuai dengan yang diminta. Hal ini sejalan dengan hasil penelitian Sudiono (2017) yang menyatakan kesalahan keterampilan proses terdaji bila peserta didik melakukan kesalahan dalam komputasi, kesalahan konsep, prosedur penyelesaian tidak dilanjutkan ata macet, dan tidak menuliskan tahapan perhitungan.

Menurut Jha (2012) dan Singh, dkk. (2010) kesalahan penulisan jawaban (endcoding errors) merupakan suatu kesalahan yang disebkan karena peserta didik tidak mampu: 1) menuliskan jawaban yang ia maksudkan dengan tepat sehingga menyebabkan berubahnya makna jawaban yang ia tulis; 2) mengungkapkan solusi soal yang ia kerjakan dalam bentuk tertulis yang dapat diterima; 3) menuliskan kesimpulan dengan hasil pekerjaannya. Pada penelitian ini, subjek penelitian yang melakukan kesalahan tersebut adalah subjek penelitian $\mathrm{A}_{8} \mathrm{~A}_{10}$, dan $\mathrm{A}_{13}$ pada soal nomor 1 , subjek $A_{10}, A_{12}$ dan $A_{13}$ pada soal nomor 2 , subjek $A_{12}$, dan $A_{13}$ pada soal nomor 3. Sedangkan $\mathrm{A}_{16}$ tidak melakukan kesalahan penulisan jawaban akhir.

Faktor penyebab terjadinya kesalahan penulisan jawaban akhir adalah peserta didik tidak menuliskan kesimpulan kesimpulan jawaban akhir dan salah menuliskan kesimpulan jawaban akhir. Hal ini sejalan dengan hasil penelitian(Sari, 2018)kesalahan penulisan jawaban akhir terjadi bila peserta didik dapat mengerjakan penyelesaian secara tepat namun tidak menuliskan jawaban akhir atau menyimpulkan jawaban akhir tidak sesuai dengan konteks soal.

\section{Kesimpulan dan Saran}

Berdasarkan hasil analis dan pembahasan yang temukan peneliti diperoleh kesimpulan sebagai berikut: (1) Persentase kesalahan membaca peserta didik sebesar 0\%.(2) kesalahan memahami (comprehension errors) peserta didik sebesar 54\%. (3) Persentase kesalahan transformasi (transformation errors) peserta didik sebesar 92\%. (4) Persentase kesalahan ketarampilan proses (transformation errors) peserta didik sebesar 54\%. (5) Persentase kesalahan 
penulisan jawaban akhir (encoding errors) peserta didik sebesar 61\%. Saran dari peneliti bagi guru diharapkan dapat memberikan solusi, dengan cara memberikan penekanan pada rumusrumus, penulisan kalimat matematika dan memberikan contoh-contoh soal berbentuk cerita lebih banyak agar peserta didik terbiasa menyelesaikan soal berbentuk cerita.

\section{Daftar Rujukan}

Abdurrahman, S. (2012). Anak Berkesulitan Belajar.Jakarta:Rineka Cipta.

Amalia, S. R. (2017). Analisis Kesalahan Berdasarkan Prosedur Newman Dalam Menyelesaikan Soal Cerita Ditinjau Dari Gaya Kognitif Mahasiswa. Aksioma, 8(1), 17-30.

Amini, S., \&Yunianta, T. N. H. (2018). Analisis Kesalahan Newman Dalam Menyelesaikan Soal Cerita Aritmatika Sosial Dan ScaffoldingNya Bagi Kelas VII SMP. Nabla Dewantara: Jurnal Pendidikan Matematika,3(1), 1-28.

Arikunto, S. (2013). Prosedur Penelitian Suatu Pendekatan Praktik. Jakarta: Rineka Cipta.

Budiyono. (2008). Kesalahan Mengerjakan Soal Cerita Dalam Pembelajaran

Matematika.PAEDAGOGIA, 11(1), $1-8$.

Jha, S. K. (2012). Mathematics Performance Of Primary School Students In Assam (India):An Analysis Using Newman Procedure. Internasional Jurnal of Computer Application Engineering Sciences, 2(1), 17-21.

Moleong, L. J. (2017). Metodologi Penelitian Kualitatif (Edisi Revisi). Bandung: Rosada.

Oktaviana, D. (2017). Analisis Tipe Kesalahan Berdasarkan Teori Newman Dalam Menyelesaikan
Soal Cerita Pada Mata Kuliah Matematika Diskrit. EduSains: Jurnal Pendidikan Sains \& Matematika, 5(2), 22-32.

Rahmawati, D., \& Permata, L. D. (2018).

Analisis Kesalahan Siswa Dalam Menyelesaikan Soal Cerita Program Linear Dengan Prosedur Newman. Jurnal Elektronik Pembelajaran Matematika, 5(2), 173-185.

Sari, R. K. (2018). Analisis Newman dalam Menyelesaikan Soal Statistika Ditinjau dari Metakognitif Tacit Use. Jurnal Tadris Matematika, 1(2), 157-166.

Singh, P., Rahman, A. A., dan Sian Hoon, T. (2010). The Newman Procedure for Analyzing Primary Four Pupils Errors on Written Mathematical Task: A Malaysian Perspective. Procedia on International Conference on Matethematics Education Research 2010 (ICMER 2010), 8(2010): 264-271.

Sudiono, E. (2017). Analisis Kesalahan Dalam Menyelesaikan Soal Matematika Materi Persamaan Garis Lurus Berasarkan Analisis Newman. UNION: Jurnal Ilmiah Pendidikan Matematika, 5(3), 295-302.

Sugiyono. (2015). Metode Penelitian Kuantitatif, Kualitatif, Dan $R \& D$. Bandung: Alfabeta.

Susilowati. P. L. dan Ratu, N. (2108). Analisis Kesalahan Siswa Berdasarkan Tahapan Newman Dan Scaffolding Pada Materi Aritmatika Sosial.Jurnal "Mosharafa",7(1), $13-24$.

Sutjipto. (2005). Apayang Salah dengan Matematika.Jakarta: Badan Penelitian dan Pengembangan Pusat Penelitian Pendidikan Depdiknas.

White, A. L. (2005). Active Mathematics in Classrooms: Word problems need not be so difficult. Square One, 15 (3), 15-19. 